\title{
Lipaemic blood: alcohol-induced acute hypertriglyceridaemia
}

\author{
Aleem Azal Ali 두, Madeline Fasen, Kintin Ng, Patrisha Shelley
}

Internal Medicine, University of Florida College of Medicine, Jacksonville, Florida, USA

\section{Correspondence to} Dr Aleem Azal Ali; a.azal.ali@gmail.com

Accepted 22 June 2021

\section{Check for updates}

(C) BMJ Publishing Group Limited 2021. No commercial re-use. See rights and permissions. Published by BMJ.

To cite: Ali AA, Fasen M,
Ng K, et al. BMJ Case
Rep 2021;14:e243167.
doi:10.1136/bcr-2021-
243167

\section{DESCRIPTION}

Hypertriglyceridaemia (HT) is a metabolic disorder characterised by elevated synthesis of triglycerides (TG) or reduced catabolism of these molecules or a combination of both. TGs are usually $<150 \mathrm{mg} /$ $\mathrm{dL}$, however, when the values are in excess of $>1000 \mathrm{mg} / \mathrm{dL}$, the supernatant of serum samples can appear lipaemic with a milky creamy aspect due to the presence of chylomicrons. Alcohol consumption affects the synthesis and metabolism of TG, with significant elevations manifesting with acute pancreatitis.

A 28-year-old man presented with nausea and abdominal pain of 48 hours duration. The patient endorsed a recent birthday celebration where he binged alcohol 3 days prior. On physical examination, the patient was haemodynamically stable, tachycardiac and markedly tender to palpation in the epigastric and left upper quadrant of the abdomen. He was started on intravenous fluids and treated with antiemetics for management of possible gastritis versus pancreatitis.

In the emergency department, the venipuncture samples collected appeared grossly lipaemic with a milky white/cloudy appearance (figure 1). As the serum appeared lactescent, this prompted the addition of lipid panel testing. Labs revealed normal $\mathrm{CBC}$ and renal function; however, lipase was elevated at $422 \mathrm{U} / \mathrm{L}(0-60 \mathrm{U} / \mathrm{L})$ suggestive of acute pancreatitis, transaminitis (AST 226, ALT 229), hyponatraemia $-126 \mathrm{mmol} / \mathrm{L}$ and TG elevated at $3029 \mathrm{mg} / \mathrm{dL}(<150 \mathrm{mg} / \mathrm{dL})$. Work-related medical examination completed 1 month prior revealed a normal lipid panel. He had no physical stigmata of HT, body mass index was $26.2 \mathrm{~kg} / \mathrm{m}^{2}$ and $\mathrm{A}_{1} \mathrm{c} 5.4 \%$. The patient endorsed an active lifestyle and worked as a carpenter.

The patient was admitted for management of acute pancreatitis likely precipitated by alcoholinduced HT. He was started on an insulin infusion along with fenofibrate. Atorvastatin was initially excluded from his treatment regimen in view of his transaminitis. Magnetic resonance cholangiopancreatography (MRCP) revealed features of pancreatitis and hepatic steatosis. The insulin infusion was continued for 36 hours and discontinued when the patient's serum TG level was $<500 \mathrm{mg} /$ $\mathrm{dL}$ (figure 2). The patient's medication regimen was optimised and he was discharged to follow up with outpatient endocrinology.

Alcohol-induced-HT relates to the ingestion of alcohol causing an increase in the synthesis of TGs and TG-rich lipoproteins in the liver. HT is often asymptomatic, at times manifesting with

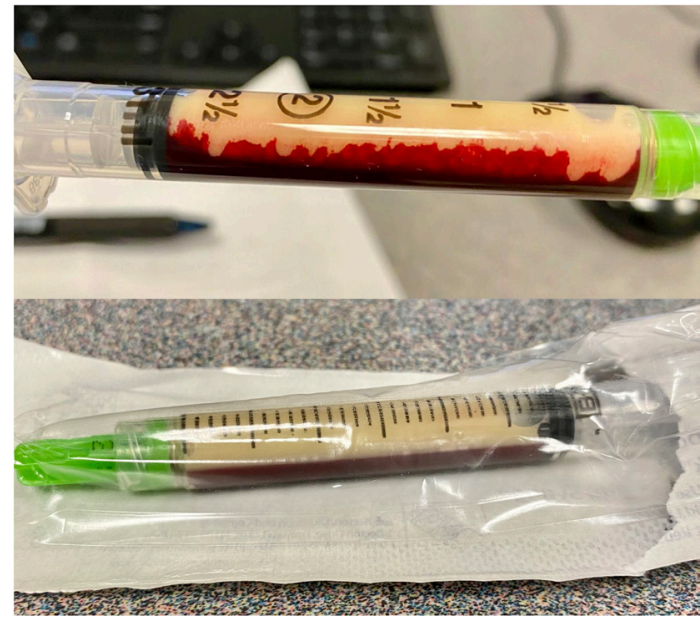

Figure 1 Venepuncture sample with grossly lipaemic blood giving a milky-white cloudy appearance.

physical findings including eruptive xanthomas and lipaemia retinalis (TGs $>4000)$. WhenTG levels are $>1000 \mathrm{mg} / \mathrm{dL}$, HT can manifest as acute pancreatitis. Using a validated predictive model for acute pancreatitis risk in patients with severe HT and taking into account risk factors such as age, presence or absence of excessive alcohol use and gallstone disease, the predicted risk of developing acute pancreatitis with excess alcohol use and serum TGs $<1000 \mathrm{mg} / \mathrm{dL}$ is $<4 \% .{ }^{1}$ Additionally, applying the same validated predicative model for acute pancreatitis in our younger patient predicted a high risk of $>12 \%$ for development of acute pancreatitis with his serum TG $>2000 \mathrm{mg} / \mathrm{dL}$ and excess alcohol use.

The mechanism of alcohol induced HT relates to the ingestion of alcohol causing an increase in the synthesis of TGs and TG-rich lipoproteins in the liver. ${ }^{2}$ Acute ingestion of alcohol stimulates catecholamines, with increased lipolysis in fatty tissue, resulting in a large supply of fatty acids to the liver. Acute alcohol consumption is also known to inhibit the enzyme lipoprotein lipase which plays a pivotal role in the metabolism of TG-rich proteins such a chylomicrons. $^{3}$

TG themselves, do not appear to be toxic, however, it is their breakdown products into toxic free fatty acids (FFA) that result pancreatic injury. ${ }^{4}$ The pathophysiology underlying TG-induced pancreatitis is incompletely understood, however, a combination two theories have been proposed. First, metabolism by hydrolysis of excess TGs released high levels of unbound free fatty acids that self-aggregate into micellar structures with detergent properties. ${ }^{5}$ These toxic molecules invoke 


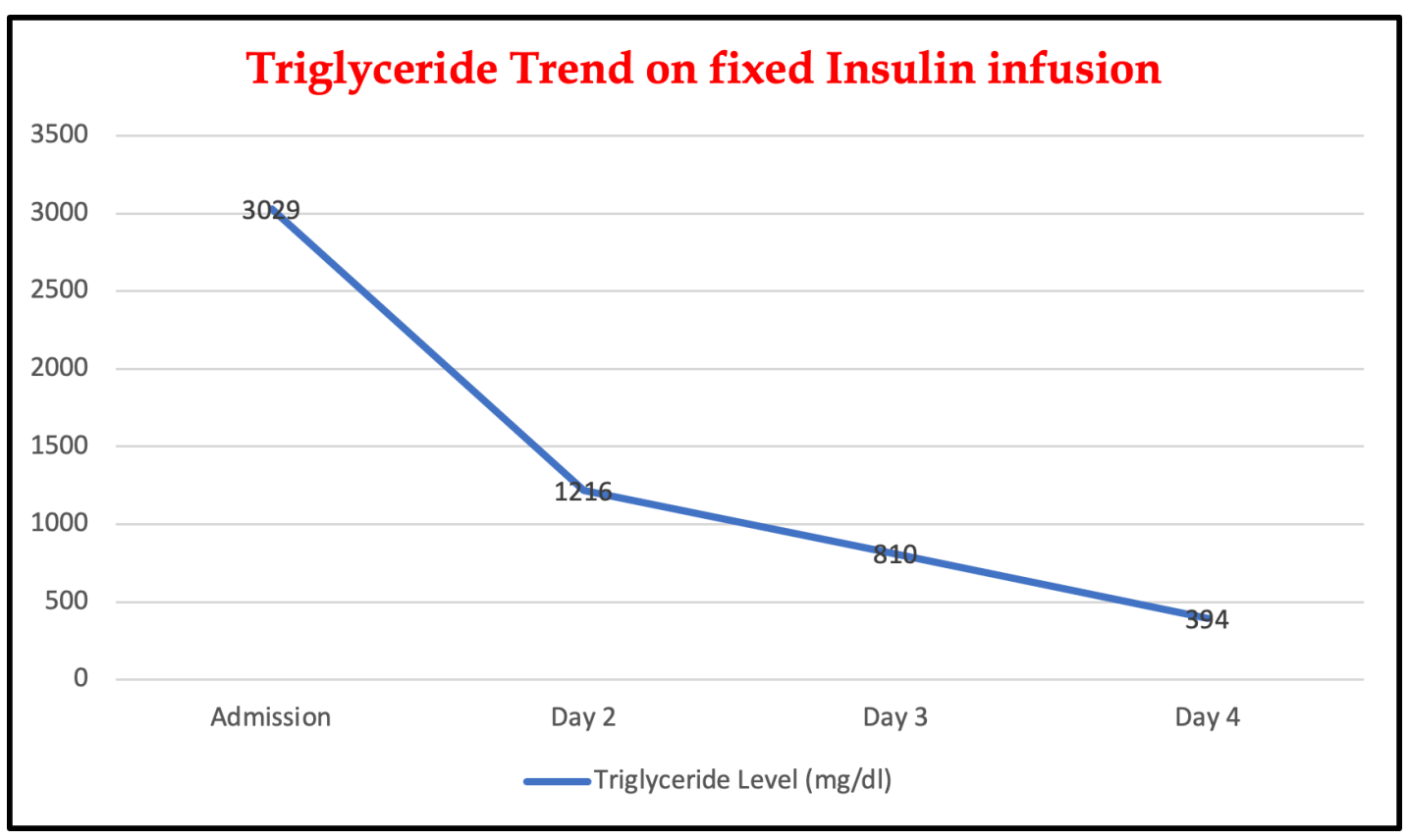

Figure 2 Triglyceride trend on fixed dose insulin infusion.

inflammation of pancreatic acinar cells, platelets and vascular endothelial cells resulting in ischaemia and acidosis. The acidosis increases FFA toxicity by activation of trypsinogen, which incites acute pancreatitis. In the second theory, elevated chylomicrons increase plasma viscosity which leads to capillary plugging and ischaemia, which enhances acidosis and again incites acute pancreatitis. ${ }^{5}$ Alcohol induced HT is transient and usually returns to baseline within $2-3$ days. ${ }^{6}$

The interaction of genetic and environmental factors contributes to the pathophysiology of hypertriglyceridaemic states. Possible aetiologies include genetic (like lipoprotein lipase deficiency and apolipoprotein CII deficiency), polygenic and secondary disorders (such as obesity, diabetes, alcohol, pregnancy and certain medications). In our case, an underlying genetic disorder likely increased our patient's susceptibility to the development of acute HT in the presence of secondary risk factors (ie, acute alcohol binge). ${ }^{7}$

Our patient fulfilled the criteria for the diagnosis of acute pancreatitis with typical epigastric pain, elevated lipase, supported by radiographic imaging. It was fortunate that the patient's milky serum prompted lipid studies, as obtaining TG measurement is not

\section{Patient's perspective}

'It was my birthday so friends said let's get lit, man I had like more than 12 shots, thought I'd just vomit, didn't figure l'd end up in the emergency with all this pain'

'Didn't think alcohol would do all this, I don't wanna see another drink'

\section{Learning points}

- To briefly discuss the effect of alcohol on triglycerides and the pathophysiology of alcohol-induced hypertriglyceridaemia.

- To highlight the clinical implications and acute management of severe hypertriglyceridaemia and acute treatme. a common initial approach in the ED. His initial hyponatraemia was likely due to excess triglycerides in the serum sample, displacing water containing sodium resulting in pseudohyponatraemia.

An insulin infusion was used to rapidly decrease the acute HT. Insulin therapy in pancreatitis associated with severe HT is used to reverse the stress-associated release of fatty acids from adipocytes, to promote intracellular TG generation within adipocytes and to promote fatty acid metabolism. Insulin also decreases serum TG levels by enhancing lipoprotein lipase activity, thus accelerating the metabolism of TGs. Insulin also inhibits hormone-sensitive lipase in adipocytes, reducing the breakdown of adipocyte TGs and release of free fatty acids into the circulation. While no clear consensus exists on management, the Endocrine Society 2020 recommends against the routine use of insulin infusion in patients without diabetes who have TG-induced pancreatitis. ${ }^{8}$

The effects of alcohol on lipid metabolism are diverse and excessive alcohol consumption is known to affect TG levels. Early detection and management of acute HT is vital to reduce the morbidity associated with pancreatitis. Acute treatment of HT-induced pancreatitis includes reduction of serum TG levels $<500 \mathrm{mg} / \mathrm{dL}$ and can require therapy with insulin or apheresis.

Contributors AAA: Acquisition of data, drafting of the manuscript. MF: Acquisition of data, drafting of the manuscript. KN: Acquisition of data, drafting of the manuscript. PS: Acquisition of data, drafting of the manuscript, critical Revision of the manuscript.

Funding The authors have not declared a specific grant for this research from any funding agency in the public, commercial or not-for-profit sectors.

Competing interests None declared.

Patient consent for publication Obtained.

Provenance and peer review Not commissioned; externally peer reviewed.

ORCID iD

Aleem Azal Ali http://orcid.org/0000-0003-4041-2301

\section{REFERENCES}

1 Morkos M, Amblee A, Henriquez A, et al. External validation of a predictive model for acute pancreatitis risk in patients with severe hypertriglyceridemia. Endocr Pract 2019;25:817-23. 
2 Hannuksela ML, Rämet ME, Nissinen AET, et al. Effects of ethanol on lipids and atherosclerosis. Pathophysiology 2004;10:93-103.

3 Schneider J, Liesenfeld A, Mordasini R, et al. Lipoprotein fractions, lipoprotein lipase and hepatic triglyceride lipase during short-term and long-term uptake of ethanol in healthy subjects. Atherosclerosis 1985;57:281-91.

4 Navina S, Acharya C, DeLany JP, et al. Lipotoxicity causes multisystem organ failure and exacerbates acute pancreatitis in obesity. Sci Trans/ Med 2011;3:107ra110.

5 Pretis N, Amodio A, Frulloni L. Hypertriglyceridemic pancreatitis: epidemiology, pathophysiology and clinical management. United European Gastroenterol J 2018:6:649-55.
6 Dominguez-Muñoz JE, Malfertheiner P, Ditschuneit $\mathrm{HH}$, et al. Hyperlipidemia in acute pancreatitis. Relationship with etiology, onset, and severity of the disease. Int J Pancreatol 1991;10:261-7.

7 Lewis GF, Xiao C, Hegele RA. Hypertriglyceridemia in the genomic era: a new paradigm. Endocr Rev 2015;36:131-47.

8 Newman CB, Blaha MJ, Boord JB, et al. Lipid management in patients with endocrine disorders: an endocrine Society clinical practice guideline. J Clin Endocrinol Metab 2020;105:dgaa674:3613-82

Copyright 2021 BMJ Publishing Group. All rights reserved. For permission to reuse any of this content visit

https://www.bmj.com/company/products-services/rights-and-licensing/permissions/

BMJ Case Report Fellows may re-use this article for personal use and teaching without any further permission.

Become a Fellow of BMJ Case Reports today and you can:

- Submit as many cases as you like

- Enjoy fast sympathetic peer review and rapid publication of accepted articles

- Access all the published articles

- Re-use any of the published material for personal use and teaching without further permission

Customer Service

If you have any further queries about your subscription, please contact our customer services team on +44 (0) 2071111105 or via email at support@bmj.com.

Visit casereports.bmj.com for more articles like this and to become a Fellow 